\title{
Romance sentence adverbs in -mente: Epistemic mitigation in synchrony and diachrony
}

Martin Hummel (Graz)

\begin{abstract}
In Romance, epistemic sentence adverbs expressing certainty often reduce the truth value of the proposition. Examples such as Fr. sûrement and Sp. seguramente convey probability and even doubt rather than certainty. This phenomenon, called epistemic mitigation, is the topic of this paper. It will be shown that the intuitive first glance impression of epistemic mitigation masks a bundle of other factors: subjectivization, inferential mitigation, politeness, "better language", and style. Italian is shown to keep to baseline subjectivization, while French, Portuguese, and Spanish tend to develop further inferential mitigation. The paper presents "ten facts" that explain the interplay of these factors at the levels of function and culture, and in both synchrony and diachrony. The paper thereby proposes a complex synthesis. Further empirical investigation will be required to test the facts and arguments presented.
\end{abstract}

\section{$1 \quad$ Introduction}

Although the adjectives in their lexical stem conceptually express "certainty", Romance equivalents to Engl. surely, certainly, etc., downgrade the truth value of the proposition (henceforth epistemic mitigation). In the following examples, the epistemic adverb expresses that the speaker strongly believes Mary has left:

1. Fr. Marie est sûrement partie déjà.

It. Maria sicuramente è già partita.

Pt. Seguramente, a Maria já foi embora.

Sp. Seguramente, María se ha marchado ya.

'Mary has surely left'

Hence, the truth value of the proposition Mary has left is downgraded by the adverb. This is at least the case for French, Spanish and Portuguese, while native speakers of Italian (including the careful reviewer of this article, to whom I am grateful) strongly affirm that It. sicuramente does not change at all the truth value of the proposition, a point I will later come back to. By contrast, the Diccionario del español actual (Seco et al. 1999; s. v. seguramente) translates Sp. seguramente with "de manera probable o casi segura" (see also Barrios Sabador 2015). To provide a natural context example, the following citation combines emphasized Sp. seguramente 'probably' with the subjunctive mode (responda): 
Muy seguramente esta elipsis [...] responda a una innovación culta para evitar la excesiva longitud de la construcción [...]

'It is highly probable that this ellipsis is an innovation in the language of the educated in order to avoid the excessive length of the construction'

(García Sánchez 2007: 426)

The syntactic position is a relevant issue for the diachronic development of sentence adverbs, but the addition of mitigation to the epistemic function does not seem to depend on syntax. Position in syntax will therefore not be discussed. I use the term "sentence adverb" in a broad sense including functions such as discourse organization, which could be excluded if sentential modification were opposed to effects on discourse taken as a major unit.

The same effect of epistemic mitigation can be observed in the independent use of the same units as affirmative answers (see Martín Zorraquino 1994; Borillo 1976), again with the possible exception of Italian:

2. Fr. - Est-ce que Marie est déjà partie?

- Sûrement.

It. - Maria è già partita?

- Sicuramente.

Pt. - A Maria já foi embora?

- Seguramente.

Sp. - ¿Ya se ha marchado María?

- Seguramente.

- 'Has Mary already left?

- Surely.'

The affirmative answer mitigates bare affirmation, e. g. It. sì 'yes', by adding a subjective component 'I highly believe so'. Context plays a crucial role: The fact that the adverb appears in the answer slot of the discourse automatically assigns the answer function to the adverb. The yes/no-type of the question leaves affirmation or negation for disambiguation. For this reason, the adverb selected has to contain positive semantic features in terms of truth in order to be interpreted as an affirmation (see Mayol/Castroviejo 2013). The choice of a given adverb adds pertinent conceptual features to the affirmation. As Hummel (2012: 161-164) shows, the answer Sp. exacto is used by persons who believe they have or pretend to have the relevant knowledge. The basic semantics of Sp. seguro is analyzed by Delbecque (2009), Vázquez Rozas (2010), and Hummel (2012: 98).

Not surprisingly, the Romance equivalents of surely are also ironically used to express the contrary 'I do not believe it at all', the irony being often but not necessarily suggested by the initial statement. This is particularly salient in French:

3. Fr. - Il veut me donner un million d'euros.

- Sûrement!

The epistemic function of the adverbs in (1) to (3) is clearly established in usage. In French, it is almost impossible to return to the basic function of verb modification, e. g. in \#Ils voyagent sûrement 'They travel safely'. The usual solution for expressing safety would be Ils voyagent en sécurité. In Italian, the alternatives would also be preferred (Viaggiano sicuri/in sicurezza). Some authors and dictionaries suggest viaggiano sicuramente as an equivalent, but this inter- 
pretation is unusual or at best very marginal (Ricca 2008). However, it seems that the use of It. sicuramente remains closer to basic event-modifying interpretations (Ramat/Ricca 1998: 194-195). A spot test in the parallel corpus Linguee (27.09.2016) shows that It. sicuramente is never translated with Fr. sûrement but with certainement or other equivalents (22 tokens). This confirms native speakers of Italian affirming that the truth value of It. sicuramente has not weakened (see above), at least not to the same degree as in French. As for English, in six cases out of 22, surely is chosen as an equivalent for It. sicuramente.

It is therefore important to see that usage sometimes differs between Romance languages (and English). The present paper does not deny such differences, they are simply not in focus. For the purpose of this paper, the striking fact is that the Fr. certainement conveys a similar reduced truth value to sûrement, although its stem contains the concept of certainty. The same holds for English. According to Simon-Vandenbergen and Aijmer (2007: 211), "[t]he use of certainly [...] occurs in a context of uncertainty rather than certainty" (see also Downing 2006). Consequently, contrastive differences in usage do not affect the mainstream effect of epistemic mitigation.

Schneider (2007: 99-100) argues, following Lyons (1977: 808-809), that the mitigating pragmatic effect is due to the fact that no modality conveys the truth value of a proposition better than the proposition itself in indicative mood. Witness the following example:

4. Fr. Marie est déjà partie.

'Mary has already left.'

In this example, the utterance takes the predication as a fact. As in every speech act, truth still falls into the speaker's responsibility. Hence, 'Mary has left' is subjectively presented as an objective fact. If we add the very strong epistemic concept 'without doubt', the utterance paradoxically seems to shed a doubt on the truth value:

5. Fr. Sans doute, Marie est déjà partie.

'Undoubtedly, Mary has already left.'

The translation shows that English produces a similar effect. This supports the assumption that epistemic mitigation is a general, possibly universal feature of epistemic adverbs. From this point of view, epistemic mitigation with adverbs other than 'no'/'yes' seems to be a truism.

Without denying this general feature, this paper will show that a more differentiated explanation is needed. The structure of the paper is simple. Section 2 presents ten facts and arguments that help in understanding epistemic mitigation. It is argued that these facts are crucial for the description and explanation of the specific type of mitigation reached with epistemic adverbs ending in -mente (long adverbs). In Section 3, I present a critical discussion of the facts and arguments. ${ }^{1}$

\footnotetext{
${ }^{1}$ I would like to add a personal remark to this. Feeling ill at ease with the immodest number of citations of my own work in this paper, it should be mentioned that the paper is part of a long-term project initiated around 1995. The project studies the word-classes of adjective and adverb in Romance, laying a particular focus on their interfaces. For this purpose, approaches from different theoretical, thematic, methodological, and empirical perspectives have been employed in order to obtain a multifaceted explanatory description. The present paper is written
} 


\section{$2 \quad$ Facts and arguments}

\section{Fact 1: Adequate methodology}

If the hypothesis suggested by Lyons and Schneider is correct, the same effect of epistemic mitigation should happen when the simplex It. sicuro 'sure' (henceforth also short adverb) is used instead of the long adverb ending in -mente, ${ }^{2}$ because both adverbs share the same stem, that is, they convey the same underlying concept of certainty. Now, in the case of Spanish, the pair seguro - seguramente is frequently quoted as a paradigmatic case of lexical differentiation, seguro meaning 'sure' and seguramente denoting something in between 'almost probably' and 'probably, but I doubt it':

6. Sp. Viene seguro.

'I'm sure s/he comes.'

Seguramente viene.

'I think s/he comes.'

Comparing the two entries, seguramente and seguro, in Fuentes Rodríguez (2009: s.v., only the former receives the commentary: "Elemento que atenúa la aserción. Presenta lo dicho sin afirmarlo por entero, como probable, o dicho por otros" "Element that mitigates the assertion. Presents what is being said without completely affirming it, as probable or said by others' (see also Garcés Gómez 1998: 302; Barrios Sabador 2015). Witness also the use of seguro as an affirmative answer:

7. Sp. $-i$ Viene?

- Seguro

- 'Does s/he come?

- Sure'

All these utterances express a lower degree of commitment than bare Viene, 'S/he comes'. The hypothesis of epistemic mitigation can therefore be corroborated in general terms. However, the hypothesis fails to explain the lesser degree of commitment to truth conveyed by the long adverb. Hence, the mitigating effect of epistemic adverbs ending in -mente requires a specific explanation. Methodologically, the examples show that the analysis of this case has to be approached from an onomasiological perspective including alternative expressions, that is, linguistic variation. The systematic analysis of alternatives would considerably improve the semantic, functional, and pragmatic description, but research often tackles single items only, e. g. a given adverb in -mente (see e. g. Hennemann 2012).

\section{Fact 2: Epistemic mitigation and subjectivity}

As argued above, even Marie est déjà partie (4), is subjective insofar as all speech acts are produced by speakers. However, in (4) the speaker presents the meaning of the utterance as an objective fact. The introduction of an epistemic adverb in the example deletes this kind of

in a phase of the project that brings all the threads together (see more details on the homepage of the Research Group "The Interfaces of Adjective and Adverb in Romance" (Hummel et al. updated 6/2018).

2 I use -mente to represent all morphological variants in Romance, e. g. -ment in French. 
objectivity, leaving the truth value to the speaker's knowledge, that is, to their subjective epistemic insights. In line with this, Lyons states:

But the very fact of introducing 'must', 'necessarily', 'certainly', etc., into the utterance has the effect of making our commitment to the factuality of the proposition explicitly dependent upon our perhaps limited knowledge

(1977: 809)

If we start analysis at the more basic level of modification in syntax, it seems important to observe that Sp. camina seguramente and its equivalents cannot be read as an adverb of manner but only as a judgement by the speaker. Being a judgement or opinion, the utterance rules out the affirmation of objectivity, reinforcing thereby the subjective epistemic value of the information. In case of ambiguity, e.g. Sp. habla curiosamente 'he speaks with curiosity'/"he curiously speaks', the situation is basically the same if the interpretation selects the second meaning.

The merely subjective perspective conveyed with epistemic adverbs is compatible with additional intensification, such as in the examples under (1). In other words, depending on prosody and context, It. sicuramente and its (close) equivalents may emphasize subjective certainty. In sum, in all Romance languages, including Italian, the introduction of an epistemic adverb foregrounds subjectivity. I name the path leading to subjectivization "Cline A". Lexicalization may establish this cline in usage.

Now, subjectivity as such may secondarily be perceived as a reduction of the truth value in comparison with (4). This secondary inference has become prominent in French, Portuguese, and Spanish. It identifies subjectivity with lower truth value ("Cline B"). As with Cline A, the epistemic adverb may additionally be used to reinforce the subjective commitment to truth, assuming the role of an intensifier (cf. Briz 2016: 113-114). In the case of Cline B, however, emphasis is added to uncertainty. This allows us to resolve the apparent paradox of mitigating and intensifying effects. Fr. Elle est sûrement venue may be both epistemically mitigated and pragmatically intensified with regard to its illocutive force. Emphatic intonation is indeed possible in all examples under (1) and (2). Cline B thus proves to be a further development of baseline Cline A.

Unlike in French, Portuguese, and Spanish, It. sicuramente expresses only subjectivity (Cline A), without following the path that inferentially weakens the speaker's subjective commitment to truth. However, if Cline B depends on inference starting from baseline Cline A, epistemic mitigation should also be possible in Italian as a contextual phenomenon, without being prominent in usage. Indeed, Schneider provides the following example, where It. penso che 'I think' "qualifies the statement containing It. sicuramente as an assumption":

B: $[\ldots]$ a me me l'ha detto la signora penso che sicuramente lo saprà meglio di noi

'It was the lady who told me. I think she surely knows it better than us'

(2007: 100)

Given that, in principle, Cline A and B are both available, for the simple reason that Cline B develops from Cline A, epistemic adverbs may individually follow the former or the latter cline at the level of context or subsequent lexicalization. Hence, this paper runs the risk of overgeneralization. However, Cline B, leading from subjectivity to uncertainty or doubt, has 
become prominent for a large series of epistemic adverbs in French, Portuguese, and Spanish, while Cline A seems to be prominent in Italian. In both cases, contextual or lexicalized exceptions are possible.

To conclude, the baseline effect of using epistemic adverbs is subjectivization, insofar as they introduce the speaker's point of view. Cline A holds to this baseline phenomenon. Consequently, the commitment to truth remains in the scope of subjectivity. The commitment may further be emphasized by the adverb. This cline has become prominent in Italian. Cline B is a development of Cline A. In the case of Cline B, subjectivization inferentially motivates the reduction of the commitment to truth, as a secondary effect, which becomes prominent in French, Portuguese, and Spanish.

\section{Fact 3: Mitigation and politeness as categorial effects}

The current discussion on Spanish seguramente takes into account the alternative of using seguro, but the pragmatic contrast is generally analyzed in terms of idiosyncratic lexicalization. The following example supposedly pronounced by a locksmith shows however that a similar effect is observed with ciertamente 'certainly'.

8a. Sp. Ciertamente, conviene que cambiemos la cerradura.

'Certainly, we should change the lock'

(8a) can be equivalently translated to other Romance languages:

8b. It. Certamente, è opportuno che sostituiamo la serratura.

8c. Fr. Certainement, il faudrait que nous remplacions la serrure.

In order to strengthen the analysis, the following examples switch from formal usted to informal tú:

8d. Sp. Ciertamente, conviene que usted cambie la cerradura.

8e. Sp. Ciertamente, conviene que (tú) cambies la cerradura.

These examples show that the adverbs not only convey subjectivity and, in this case, epistemic mitigation, but also formal politeness, that is, a discourse marked by personal distance (Koch/Oesterreicher 2011). Reading the formally ambiguous first person plural example (8a), one immediately infers that the speaker would use the polite third person form of address in singular (Sp. usted, It. lei, Fr. vous). (8d) and (8e) are meant to test this. Indeed, the combination with informal tú sounds odd. Obviously, formality is also conveyed by conviene que 'it is convenient that', but the fact is that the lexical and syntactic networks of the utterances only match in (8a) and (8d) at the level of register.

Since formal politeness scarcely matches with the European Spanish tendency of preferentially using informal second person tú for address, (8a) seems rather odd or unrealistic. I have indeed cited the example from a manual of American Spanish (Hernando Cuadrado 2006: 31). The context being trivial, the utterance can be considered unusual, even in those American Spanish varieties which use usted as the default form of address. By contrast, the French example could more easily be heard, at least if we somehow simplify it: Certainement, il faudrait remplacer la serrure, a fact which could be related to the historical aspects outlined in 
Fact 8, formal politeness being more accepted and generalized in France. The deeper formal politeness penetrates usage, the higher will be the frequency of utterances such as $(8 \mathrm{a}-\mathrm{d})$. Although acceptance displays cross-linguistic variation, all the examples go hand in hand with formal, distant politeness. Distance is often intended to be respectful. It thus aims to preserve the image of the interlocutor (see Barrios Sabador 2015, on Sp. seguramente), but arrogance and irony are possible as well (e. g. Fr. sûrement in answers).

The use of the long adverbs in contexts of formal politeness clearly comes to light in American varieties of Spanish. In the Spanishes of America, the overall default form of the adverb used in informal oral communication is identical with the adjective, the same as in informal spoken English (Hummel 2014a), e. g. hablar claro 'to speak clear', where the term "short adverb" is used. This is illustrated by the following examples taken from a corpus with telephone conversations recorded in Uruguay (Orlando 2006: 51, 83, 82, 105, 109). The interlocutor receiving the calls works at the service counter of an energy provider. This person is trained to be respectful and polite. The people calling are clients who in most cases complain for some reason. They tend to use the informal oral standard. Thus the pragmatic structure of the conversations opposes two communication styles marked by the contrast "politeness vs. everyday directness". ${ }^{3}$ In these dialogues, only the employee (E) consistently uses long adverbs, while the clients $(\mathrm{C})$ prefer the default short adverb:

9. E - ¿a nombre de Juan Pérez?

C - exacto

E - no tengo información lamentablemente pero pasamos el aviso

E - ' in the name of Juan Pérez?

C - exactly

E - I'm afraid, I have no information on it, but we pass the notification on'

E - muy bien. el reclamo quedó ingresado caballero lamentablemente no tengo información para brindarle hasta el momento

E - 'fine. the complaint is registered, caballero, unfortunately I don't have any information for the moment'

E - ¿es toda la zona o solamente allí?

C - no. somos cuatro o cinco vecinos que estamos sin luz y yo hoy había avisado y vino y ahora se volvió a cortar

E - bueno. reiteramos el pedido nuevamente va XX por allí

C - tá. Bárbaro

E - correcto?

C - gracias

E - a las órdenes

C - ta luego

E - ' is the whole sector affected or is it only you?

C - no. we are four or five neighbors without electricity and I had informed you today and the man came and now it cut off again

$\mathrm{E}-\mathrm{ok}$, we restate the claim again $\mathrm{XX}$ goes there

\footnotetext{
${ }^{3}$ Martín Zorraquino (2015: 51-52) analyzes this contrast in terms of direct responsibility (short form) and shared responsibility (long form).
} 
C - all right. Great

E - correct?

C - thanks

E - you're welcome

C - bye'

C - Este local tiene una potencia de 200 kilowats

E - Sí

C - Este yo quería bajarlo a 30

E - No hay problema se le puede bajar perfectamente. El período es por dos años nada más.

C - Sólo por dos años

E - Exactamente Al término de dos años vuelve de vuelta a la a la [sic] potencia original

C - Y no se puede volver a bajar.

E - Se puede volver a bajar pero ahí ya definitivamente.

C - Ya queda definitivo.

C $\quad$ - 'This place has a power limit of $200 \mathrm{kw}$

E - Yes

C - I would like to reduce it to 30

E - No problem, we can reduce it for you, no problem. The term is two years, that's all

C - For two years only

E - Exactly. After two years you return to the initial power limit.

C - And we cannot repeat the reduction

E - That's possible but then it's definitive

C - It becomes definitive'

"E" may use the short (default) form as well, but s/he generally prefers the long form. Only one client among the many clients documented in the corpus manifests a similar preference for the long adverb, albeit less than "E" (Hummel 2012: 308-310).

In the oral corpus (Cresti/Moneglia 2005) analyzed by Kortschak/Hummel (2018, see below), some of the educated speakers (university level) prefer long adverbs, while none of the speakers with lower levels of education shows the same tendency. This means that at the most educated level, speakers individually follow common default or prefer a "better style". In a study on spoken Mexican Spanish, speakers with lower education level interviewed in the city of Mexico tell that they use adverbs in -mente as the "variant of linguistic prestige" (Arjona Iglesias 1991). Similar observations have been made by Hummel (2000) for Brazilian Portuguese. In sum, evidence provided by several studies support the association of long adverbs with politeness and "better style/language" (cf. Brenes Peña 2013: 51, on Sp. sinceramente). The examples quoted in (9) provide evidence for the fact that the close relationship between long adverbs and formal politeness is not restricted to epistemic adverbs. Epistemic adverbs seem to share this feature with a larger series of sentence adverbs.

Not surprisingly, Fuentes Rodríguez (2009: 66) associates the usage of long sentence adverbs with the discourse of politicians. These discourses are polite and eloquent, but people feel at 
the same time that the politicians feel less committed to what they say. In Italy, the comedian Antonio Albanese is known for his role as Cetto La Qualunque, a local Calabrian politician who exaggerates the usage of the long adverbs in his discourse, creating new, completely unknown forms such as that used for the title of his 1991 film Laqualunquemente (lit. 'whicheverly') (see https://en.wikipedia.org/wiki/Qualunquemente, [29.6.2016]). Another context of usage would be very polite sellers' discourse. The Spanish example (8a) is strange because the discourse is placed in the everyday context of the banal duty of repairing a door. One more easily imagines this type of discourse in a luxury shop. In line with this, some authors observe that long adverbs personalize the speaker's commitment for both himself (a rather personal, subjective commitment to truth) and the interlocutor (personal respect). The effect comes to light if in example (8a) ciertamente is replaced by por cierto. A similar contrast has been observed for Sp. efectivamente and en efecto (Solís García 2012: 252; see also Landone 2009: 312-313). However, the authors do not provide any explanation for this.

To conclude, courtesy is not an idiosyncratic fact concerning some adverbs, e. g. Sp. seguramente as opposed to seguro, but a categorial feature of sentential adverbs in -mente, including in Italian, at least in terms of a general tendency. In languages that follow Cline B, courtesy goes hand in hand with reduced truth value, a case that is prototypically associated with political discourse (see also Fuentes Rodríguez 1991: 291). The pragmatic effect of politeness is not restricted to epistemic adverbs, but is a broader categorial feature that includes other types of sentence adverbs.

\section{Fact 4: Sentence adverbs as lexical interculturalisms}

In the conversations cited under (9), the Spanish long adverbs can be replaced in almost all cases by the lexical and morphological equivalents in Italian and Portuguese:
10. Sp. lamentablemente
It. (disgraziatamente)
Pt. lamentavelmente
Sp. nuevamente
It. nuovamente
Pt. novamente
Sp. perfectamente
It. perfettamente
Pt. perfeitamente
Sp. exactamente
It. esattamente
Pt. exatamente
Sp. definitivamente
It. definitivamente
Pt. definitivamente

The same is possible for French except for the first case, where malheureusement would be preferred. Nouvellement is possible, but usage favors de nouveau. It. lamentevolmente exists, but it is not used as a sentence adverb. These minor differences in usage and lexical preference do not call into question the fact that there is a general tendency towards analogue usage in Romance (cf. Gil 1995). From the semantic point of view, etymologically related intercultural units show that languages use similar concepts for epistemic values (Ramat/Ricca 1998: 215). As far as basic semantics is concerned, this can be explained by universal properties of thinking, but the fact that the same etymological stem is used for this purpose provides strong evidence for linguistic and cultural contact, that is, a shared intellectual mainstream. Borrowing gives rise to the question of which language is the one that serves as a model. Roughly speaking, Latin played a major role, at least during the period of formation of written Romance languages (cf. Ramat/Ricca 1998: 238, on the direct or indirect borrowing of Lat. securus), but also later in intellectual discourse, followed by the models of Italian (Renaissance), French (absolutism), and, presently, English (see below). 
Importantly, the intercultural usage of long sentence adverbs with the same lexical bases can be extended to the English language. All items in (10) can be transposed to English: lamentably, newly, perfectly, exactly, definitively. The first one is rather exceptional, especially if used as a sentence adverb, but the following citation provides an example:

Lamentably, he did so while his giant opponent reeled with one of the lousiest little things in all of human life: a foot blister

(Washington Post, 15.07.2017)

Witness also the following pairs in Spanish and English (cf. Hummel 2013b):

$\begin{array}{ll}\text { 11. } & \text { absolutamente } \\ \text { aparentemente } & \text { absolutely } \\ \text { efectivamente } & \text { effectively } \\ \text { normalmente } & \text { normally } \\ \text { obviamente } & \text { obviously } \\ \text { prácticamente } & \text { practically } \\ \text { realmente } & \text { really } \\ \text { simplemente } & \text { simply } \\ \text { totalmente } & \text { totally }\end{array}$

This series includes intensifying modifiers of adjectives (really/totally good). It is noteworthy that analogous forms do not necessarily provide the same diachronic results, as in the case of Engl. actually 'in fact' and Fr. actuellement 'at present' (Simon-Vandenbergen/Willems 2011), where English conserves the primitive meaning. German borrowed aktuell 'at present' in the $18^{\text {th }}$ century from French, which was the language of international prestige (Kluge 2002: s. v. aktuell). Hummel (2013b) criticizes the English lexicographic tradition of systematically attributing the usage of such pairs to linguistic contact with French in that, in many cases, the shared tradition of written, spoken and, in particular, read Latin provides a more coherent explanation for the common tradition, which is not restricted to French and English but includes Romance in general.

As far as epistemic mitigation is concerned, the equivalents listed in (12) have a similar capacity of downgrading the truth value, especially if compared with the short form used as a sentence adverb, except for Italian, where native speakers claim an unchanged truth value for sicuro and sicuramente. In the latter case, the relevant difference between both is a matter of syntax, register, and code:
12. Fr. sûr
sûrement
It. sicuro
sicuramente
Pt. seguro
seguramente
Sp. seguro
seguramente
Engl. sure
surely
Ger. sicher
sicherlich

The German suffix -lich in sicherlich is etymologically related to Engl. -ly. As its English counterpart, it was originally used as a means for deriving adjectives from nouns, as in Ger. Freund to freundlich, which are morphologically and semantically equivalent to Engl. friend and friendly. Sicherlich is an exception because it is only used as an adverb, not as an adjec- 
tive. However, the pragmatic differences follow the same pattern. In German, the answer " $\mathrm{Si}$ cher!' means 'I am sure!', while sicherlich expresses 'I think so; probably'. This difference may be described in terms of directness. The short form is direct, while long form is more indirect, similar to the conversational contrast in (9). In all the lexical pairs cited above, the short adverbs express direct subjective evaluation, while the long adverbs include a more distant, reserved, and possibly respectful attitude.

It is noteworthy that the short variants of many sentence adverbs are more in use than grammars make us believe. In informal French, the following examples can be easily heard (Hummel 2018b):

13. Normal, il pouvait pas savoir.

Curieux, il m'a pas appelé.

Bizarre, elle a pas accepté.

Incroyable, mais elle l'a épousé quand même.

Sérieux, elle t'a dit ça?

Grammars generally do not mention these variants but only the long variants ending in -ment. This is, in the first place, due to the fact that long adverbs are considered to be members of the word class of adverbs, while the status of the short adverbs is less clear. Consequently, only the long forms figure in chapters on adverbs. Secondly, traditional grammars generally rely on the written language, in which the usage of the short form is highly stigmatized. It was the discussion on discourse markers initiated by Weydt (1969), Gülich (1970), and Schiffrin (1987) that shed a new light on the similarities of the short and the long forms in the domain of discourse functions. The traditional term "sentence adverbs" prototypically focuses on the long forms only. But the long forms clearly compete with the short forms for the expression of epistemic evaluation.

Again, Germanic languages display a similar situation (Hummel 2014a). In the case of German (and Dutch), this is rather surprising, inasmuch as German canonically uses the "unchanged" adjective for adverbial functions, the only noteworthy exception precisely being sentence adverbs, which are marked by the suffix -erweise. As also in Dutch, grammars of German only quote long sentence adverbs ending in -erweise. With reference to the French examples under (13), canonical German would provide the equivalents normalerweise, komischerweise, eigenartigerweise, unglaublicherweise, and, less frequently, ernsthafterweise. However, everyday spoken German prefers normal, komisch, eigenartig, unglaublich, ernsthaft.

\section{Fact 5: Long adverbs in the tradition of writing}

In line with the orality-literacy split of short and long adverbs observed in the previous section, overwhelming empirical and intuitive evidence shows that long adverbs are strongly tied to the implementation of writing in diachrony. Anecdotes such as the commentaries on hypercorrect Engl. firstly (Hummel 2014a) may be added. The historical movement of Les Précieuses, claiming the usage of French long adverbs in their very refined register, is a culmination point (Hummel 2012: 311-312). With regard to quantitative empirical evidence, Chafe (1982), and especially Biber (1988) and Biber et al. (1999), have brought to light the prefer- 
ence of written English for adverbs in -ly. Diachronically, Old English followed the general Germanic tradition of using a neuter form of the adjective for adverbial functions. While adverbs in -ly were progressively used in Middle English, the systematic replacement of short adverbs by adverbs ending in -ly is clearly related to the implementation of written modern standard English. As shown by Hummel (2014a, 2018a), the standardization of English followed the general Western preference for using morphologically marked adverbs for writing, whereas the original Indo-European oral tradition is mainly based on the usage of the adjective (or the less marked form of the adjective) for adverbial functions (e. g. also British dialects; see the survey by Tagliamonte 2002). This is the reason why short adverbs are characteristic of the informal oral use, following the genuine oral tradition. Attempts to establish standards of writing recurrently implemented suffixed adverbs (Greek $-\omega \varsigma$, Lat. $-\bar{e}$ [long vowel] and -iter, Late Latin -iter, Romance -mente, Engl. -ly, German -erweise [only sentence adverbs]). Not surprisingly, these suffixes are generally lost or weakened as standards vanish (Greek, Latin). In the same vein, the German adverb sicherlich, discussed above, has to be situated, diachronically, in the historical context in which German, similarly to English, tried to implement the suffix -lich (cf. Engl. -ly) as a morphological mark for adverbs in written standard (Pounder 2001). This function of -lich has become unproductive in Modern German. Returning to anecdotes, German consequently had the adverb erstlich, with clear morphological, conceptual, and functional analogy to Engl. firstly. While erstlich disappeared, following the ill-success of adverbial -lich, Engl. firstly is still in use, albeit often considered as a hypercorrect alternative to first. It is noteworthy that Sp. primeramente produces the same stylistic effect in contrast with primero.

For Romance, the corpus-based studies realized by Company Company (2012, 2014a, 2017) show that the expansion of the Spanish suffix -mente correlates with the implementation of written Spanish. Using the same corpus, Hummel (2014b) provides complementary evidence for the fact that the usage of the short adverb decreases as standardization increases. Bischoff (1970: 45) and Kofler (2007) adduce variationist evidence for both French and Italian preferring adverbs in -mente in written standard (e.g. newspapers), while both literary texts and substandard more easily accept the short variant up to the point that the latter generally prevail in slang texts. Diepeveen (2012: 165-174) shows for Dutch that the progressive implementation of the suffix - erwijs for sentential adverbs follows the process of standardization (with particular acceleration in the $19^{\text {th }}$ century; see Figure 2 below). Pounder (2001) also relates the usage of morphologically marked (= long) adverbs in English and German with the process of standardization.

Consequently, the pragmatic effect of politeness conveyed by long adverbs has to be seen in the context of the fact that these adverbs are considered to be more correct than the short forms, that is, they are perceived as "better English", "better French", and so on, the general background being the prestige of the written language.

\section{Fact 6: Osmosis from writing to speaking}

It should not be overlooked, however, that many long adverbs have deeply penetrated the spoken language. This is particularly true for sentence adverbs and intensifiers (see examples under (11)). The following figure from Kortschak/Hummel (2018) displays the frequencies of 
the ten most frequent adverbs in -mente in the European Spanish part of the oral corpus $C$ Oral-Rom (Cresti/Moneglia 2005; see also Bilger 2004 for French):

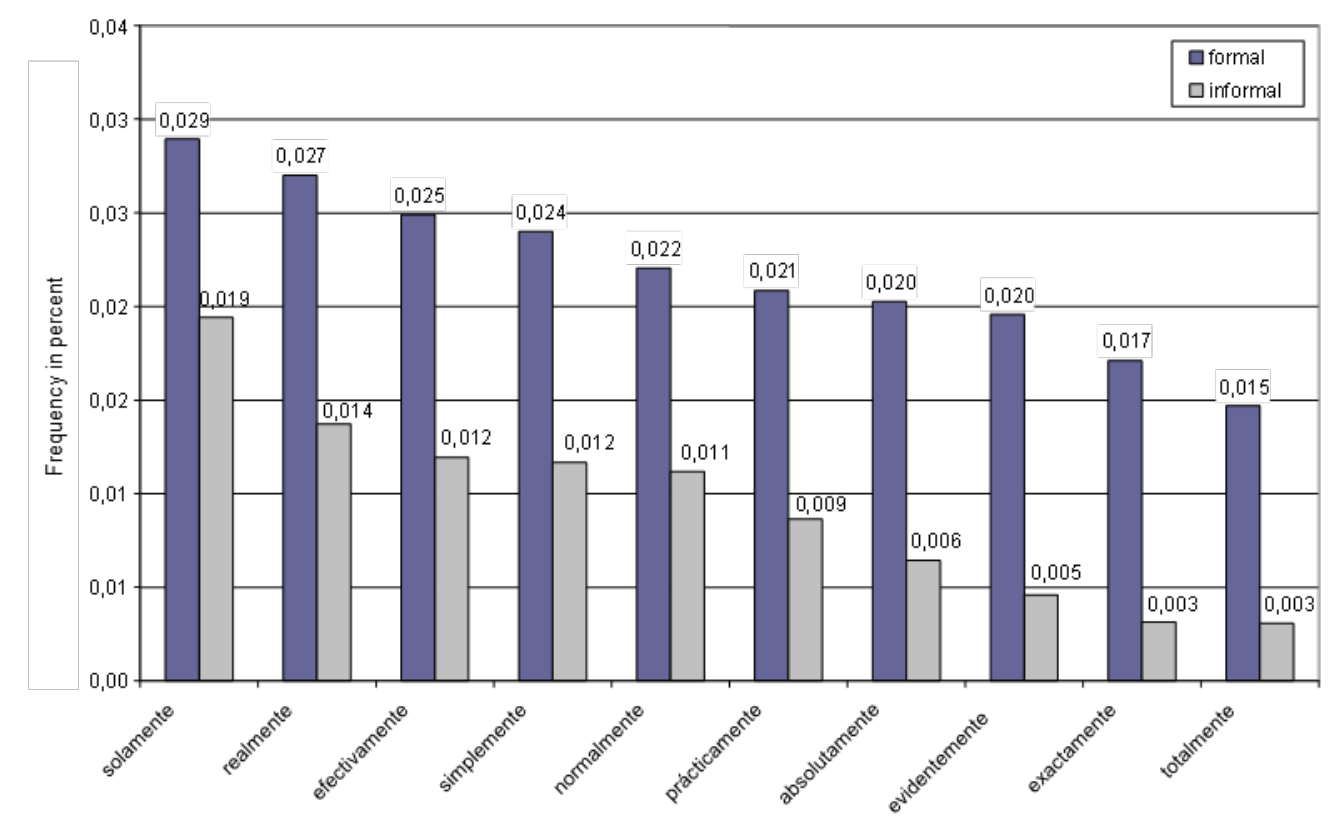

Figure 1: Most frequently used long adverbs in formal and informal spoken Spanish

While the items are exactly the same in the formal and informal registers, their frequency in formal language is, on average, three times higher than in the informal registers. In addition, educated speakers (graduated) use them three times more frequently than other speakers. This quantitative contrast between formal and informal language provides evidence for the direction of the diffusion process, which goes from the written language of the educated via the spoken educated language to the informal spoken language. This Spanish data is in line with Biber's analysis of long adverb usage in formal and informal spoken English. It would be interesting to see which of the long adverbs most easily penetrated English dialects with their tradition of preferring short adverbs.

The propagation of long adverbs from literacy to orality is not a matter of general diffusion but of osmosis, that is, selective diffusion. Grammars consider verb modification as the core function of manner adverbs. This has been empirically corroborated by diachronic corpus studies (Company Company 2014; also see Ricca 2008), even if the predominance of - particularly descriptive - literary texts in most diachronic corpora probably somehow biases this result. However, it is not verb modification that best penetrates oral registers but discourse functions in their broadest sense. This means that the functions created by transposition from baseline verb modification are best accepted in spoken language.

Table 1 compares the frequencies of short and long adverbs according to their function in data drawn from semi-informal spoken Chilean Spanish (details in Hummel 2013a): 


\begin{tabular}{|c|c|c|c|c|}
\hline & \multicolumn{2}{|c|}{ Short adverb } & \multicolumn{2}{|c|}{ Long adverb (-mente) } \\
\hline & Types & Tokens & Types & Tokens \\
\hline Verb modif iers & 26 & 40 & 5 & 5 \\
\hline Discourse markers, sentential adverbs & 11 & 395 & 9 & 61 \\
\hline Quantif iers & 10 & 202 & 6 & 11 \\
\hline Adverbs of time & 12 & 40 & 5 & 12 \\
\hline Total number & 59 & 677 & 25 & 89 \\
\hline
\end{tabular}

Table 1: The functions of short and long adverbs in spoken Chilean Spanish

In all functions, the type and token frequencies of the short adverb are higher than the frequencies of the long form. This mirrors the default status of short adverbs in spoken American Spanish. The fact that verb modification attracts the largest number of short adverb types shows that this function is indeed required in informal oral registers, but token frequency also indicates that it is, by far, not as frequently used as the other functions. If we look at the internal distribution of functions realized by long adverbs, we see that sentence and discourse oriented functions prevail over the other functions. Consequently, the process of long adverb osmosis selectively favors discourse functions. The functional domain less penetrated by long adverbs is precisely verb modification, unlike in written Spanish, where this domain is the prototypical one.

\section{Fact 7: A diachronic phenomenon in modern Western languages}

The creation and expansion of long sentence adverbs ending in -mente (cf. similarly Engl. -ly, Ger. -erweise, Dut. -erwijs) is a diachronic process (i) located in the Western Greco-Latin cultural tradition, (ii) situated in what is generally called the modern epoch of language (starting from the $16^{\text {th }}$ century), (iii) that culminates in the $20^{\text {th }}$ century where long sentence adverbs are canonized. This rough generalization can be drawn from the many corpus studies that have recently been dedicated to the diachrony of long sentential adverbs. In the following graph, the curve provides an idealized representation of the development of discourse functions expressed by long sentence adverbs: ${ }^{4}$

\footnotetext{
${ }^{4}$ I have consulted the studies on broader samples by González de Requena Farré (2015), Ricca (2008), Company Company (2014a, b), Gómez-Jordana (2010, 2011), as well as studies on single items: Sánchez Jiménez (2008) on Sp. naturalmente, Rodríguez Somolinos (2012) on Fr. apparemment, Rivas and Sánchez-Ayala (2012) on Sp. efectivamente, González Manzano (2010) on Sp. verdaderamente. In the case of verdaderamente, the function as a modifier of adjectives (intensifier) also follows the curve in Figure 2. Killie (2015) considers the development from the point of view of secondary grammaticalization. Cf. Swan (1991), which is however not restricted to long adverbs.
} 


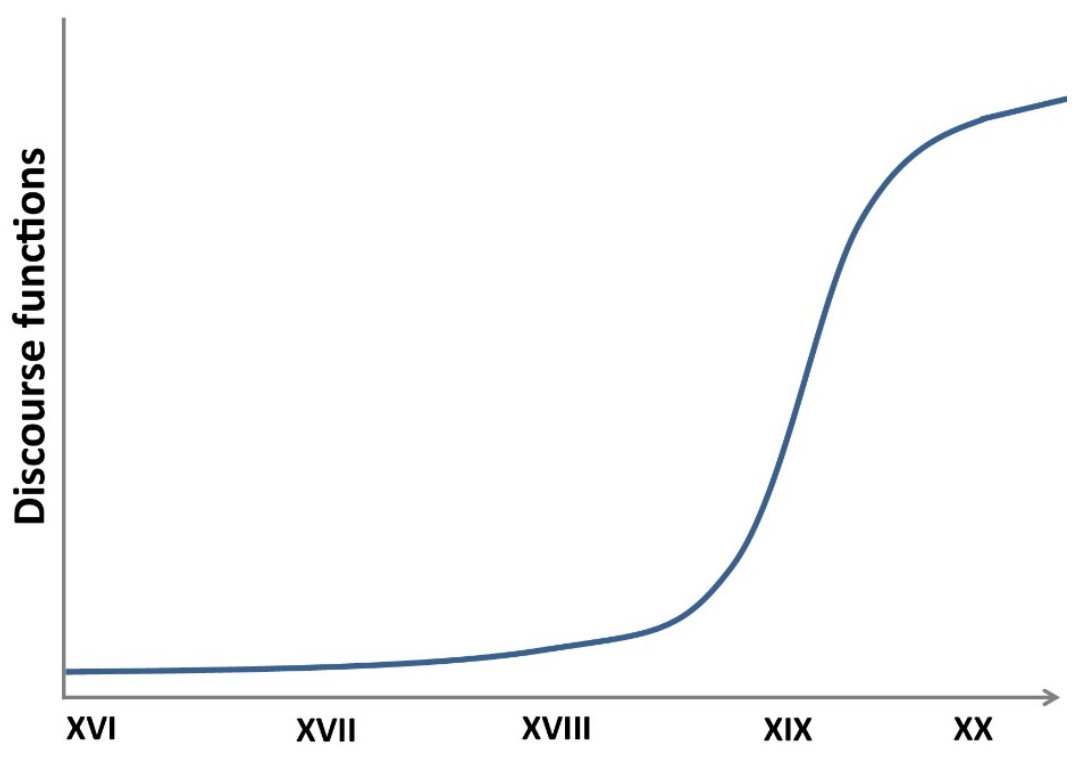

Figure 2: Idealized diachrony of long sentence adverbs

Until the sixteenth century, discourse functions of long adverbs are scarcely attested. It is generally recognized that they emerge from the basic function of verb modification. This analysis has to be differentiated with regard to certain aspects (see discussion in Section 3), but these considerations do not call into question the general tendency of transposition from the core domain of verb modification to peripheral functions. Since many long sentence adverbs develop several discourse functions (polyfunctionality), the continuous line is meant to show the whole process of functional expansion. The curve is likely to hold for several languages sharing the same Western Greco-Latin tradition (Romance and English, as well as Dutch and German - the latter only for -erwijs and -erweise used for sentence adverbs). This parallelism requires a socio-historical explanation surpassing the limits of single languages or closely related families such as Romance or Germanic. The shared Western culture provides this explanation.

Most studies on the grammaticalization of long adverbs adopt a simple semasiological perspective. Consequently, the grammaticalization of naturally 'obviously' appears to be an internal development from naturally 'in a natural way', 'by nature'. This may obviously be the case. But the high prestige of the long adverbs in the $16^{\text {th }}$ and $17^{\text {th }}$ century and their canonization in standard also engaged a process of substitution. Until the $16^{\text {th }}$ century, adverbials combining prepositions with nouns or adjectives were widely used in all Romance languages (e.g. Sp. de seguro), declining later. Hence, long adverbs may have taken up functions previously realized in alternative ways. A brief look at the Spanish CDH corpus shows that con efecto long precedes efectivamente, which rises in usage in the $16^{\text {th }}$ century. Hummel (in print; also see Lavale-Ortiz In print) shows that Sp. de fijo, a la fija, en fija 'sure' create epistemic discourse functions from their first attestation, which are later taken up by fijo (short adverb) and fijamente. The prestige of the long adverbs thus involves a sort of "sponge effect" with regard to functions previously realized by other units in the same onomasiological domain.

Communicative necessity has played a role as well. The development of new types of text and discourse, e. g. in the $19^{\text {th }}$ century for science and academic discourse in general, created such necessities. Argumentation related to points of view in terms of opinion or specific domains 
became prominent (e. g. historically). Indeed, De Cesare et al. (forthcoming) show that domain adverbs rise in scientific discourse during the $19^{\text {th }}$ century.

\section{Fact 8: The "French style"}

In French and Spanish, the $17^{\text {th }}$ century has repeatedly been identified as a century of rupture with linguistic traditions (e.g. Eberenz 2009; Company Company 2014a, b; Hummel 2018a). The period from 1650 to 1750 is considered the one where adverbs in -mente were fashionable and thus excessively used (e.g. Glatigny 1982, 2005; Company 2014a: 519). According to Thompson and Mulac (1991: 314, 319), high frequency often precedes or generates polyfunctionality. Obviously, this applies even more when high frequency goes hand in hand with fashion and prestige, as in the case of $17^{\text {th }}$ century adverbs in -mente. In this sense, the sharply rising curve in Figure 2 is a natural or probable consequence of high frequency and fashion in a previous stage. Fashion made it attractive to transpose long adverbs to compatible peripheral positions and functions. This is what purism and rationalism later considered an excessive or abusive usage of long adverbs (see below). Short adverbs were in turn progressively marginalized in this period (Hummel 2014b).

The cultural radiance of French absolutism contributed to the transcultural propagation of the "French style", a newly created model of writing and speaking. This style was directed against the cumbersome baroque style characterized by appositions, parenthetical adjectives, clumsy enumerations and a general preference for declamatory speech, that is, an exaggerated concept of orality that transforms the addressees into an audience, as in the following two examples from Italian poetry and Spanish prose:

14. L'odio c'hai tu nel core,

te, Donna, odiar m'ha fatto, odiar Amore.

Odio dunque, e non amo: o pur, s'am'io,

amo sol l'odio mio:

e t'odio sì, che spesso

sol per averti amato, odio me stesso.

(Marino (1614), La lira: "Guerra di baci”)

15. De los balcones del cielo se apeó la claridad, habiendo visto la milagrosa hermosura de la dama aurora, fresca, hermosa y gallarda, en cuyo rostro, hiriendo suavemente el sol, temeroso en parte de los cabellos hermosos, que al descuido hondeaba por sus espaldas, descubriendo un color blanco y encarnado, afrenta del jazmín y rosa, que entre albahaca y arrayán, componía bella guarnición a sus sienes, bordado el vestido de lirios y azucenas, con guarnición de claveles y botones de azahar (Francisco Santos 1671: 135)

Against this, the new style claimed the principles of fluidity, eloquence, readability (often tested by reading out loud), and moderation. 
The Spanish diplomat Francisco Gutiérrez de los Ríos y Córdoba, earl of Fernán Núñez, set out to propagate the new French model, not only as a language style but as a general life style. In his manual for the new 'man of the world', El hombre práctico (1686), he declared the baroque style to be the model of the past, while the 'French style' is claimed to be the model of the present and the future:

La lengua francesa es preciso saber hoy con perfección, así por lo mucho y bueno que hay escrito en ella, como por lo general es casi en toda la Europa, donde hay rara corte de príncipe o república donde no se hable mejor o igualmente que las maternas.

(Gutiérrez de los Ríos y Córdoba 1686: 137)

According to this author "sin moderación la elocuencia se convierte en locuacidad" ("without moderation, eloquence becomes loquacity'). He consequently writes his manual in the new style. We thus find only a few parenthetical adjectives, three in the whole book, which is less than in the single quotation of Spanish baroque style in (15). He sticks to long adverbs where traditional texts also admit short forms, e. g. ordinario as an adverb of frequency 'usually': ordinariamente, meramente, bastantemente, enteramente, puramente, especialmente, juntamente, demasiadamente, nuevamente, justamente, diariamente, falsamente, ampliamente, fácilmente, firmemente, ligeramente. The short forms of these adverbs are all attested in texts from the $13^{\text {th }}$ to the $16^{\text {th }}$ century, while they got almost out of use in Modern written Spanish standard. Some of the long forms were soon considered to be hypercorrect (bastantemente, demasiadamente), which is another hint for negatively identifying the fashionable trend of developing and using the long forms in the $17^{\text {th }}$ century (compare with Engl. oftenly, soonly, firstly in Hummel 2014a, also see Hummel 2013b).

The guide for the "man of the world" written by a Spanish diplomat is only an example, but the principle of moderation has been identified as the major feature of literary classicism. It has become famous as the "Klassische Dämpfung" ('classical moderation or attenuation'), a term created by Leo Spitzer (1931). Declamation and stylistic cumbersomeness were replaced by narrative and fluid moderation. Long adverbs in -mente played a major role for this purpose. Hence, there is an interesting parallelism between present-day epistemic mitigation and politeness and the historical context of "classical moderation". Linguistic mitigation is a natural device for communicative moderation.

The French model expanded to other languages. In her contrastive study on Fr./Sp. justement/justamente, apparemment/aparentemente, décidément/decididamente, Gómez-Jordana (2010) analyzes parallel processes of secondary grammaticalization of discourse functions in diachrony. In this process, French precedes (and possibly influences) Spanish. Another example is Rumanian. Due to late standardization in the $19^{\text {th }}$ century, Rumanian has canonized the oral tradition of using unchanged adjectives for adverbial functions (short adverbs). As standardization aimed at drawing Rumanian nearer to Romance, intellectuals concerned with standardization made an unsuccessful effort to introduce the suffix -mente. As a consequence of their failure, the new sentential functions were realized by short adverbs with the same lexical basis as long sentence adverbs in other Romance languages. Chircu (2008: 126) quotes the following sentence adverbs: absolut, bizar, evident, logic, normal, posibil. Most, if not all of them, followed the French (and Italian) model (see Maas 2012: 195-197, for German; also see the remark on Ger. aktuell under Fact 4). 
The ideal of fluidity and elegance is a model still in use in present times. Although innovative literary style has abandoned the classical model, people still use this elegant narrative style. Moreno de Alba, the former president of the Mexican Academy, used to begin his journalistic "Minutiae (on language)" as follows (Minucias: 52, 283, 351, 467):

16. Evidentemente estas notitas tienen siempre como sujeto algún aspecto de la lengua española.

Ciertamente no existen en la lengua sinónimos perfectos.

Excepcionalmente me referiré a un asunto de lexicografía inglesa elemental [...].

Recientemente ha venido apareciendo, sobre todo en el lenguaje periodístico [...]

It is noteworthy that in the second half of the $16^{\text {th }}$ century, upcoming linguistic purism turned against the excessive usage of long adverbs. Still later, $18^{\text {th }}$ century rationalism criticized in particular the usage of long sentence adverbs as a violation of the principle of clarity and logic. It was argued that the metaphorical transposition of the basic concept to a figurative target domain in cases such as curieusement 'curiously' = 'strangely' or naturellement 'naturally' = 'obviously' corrupts logical argumentation. As a consequence, the normative discourse recommended the use of paraphrases such as de manière naturelle 'in a natural way' or avec curiosité 'with curiosity' (Hummel 2018a). As shown in Figure 2, this critique had no substantial effect on the usage of long sentence adverbs, except for the fact that French writers generally avoid creating new long adverbs (Bally 1965: 246-248). At least in the case of French, in the $20^{\text {th }}$ century the curve ascends more slowly not only because the communicative demand is saturated but also because canonization restricts the number of accepted sentence adverbs.

\section{Fact 9: Transposition}

The historical and cultural explanation suggested for the expansion of long sentence adverbs is so to speak the sufficient part of the explanation, which means that the necessary part is still lacking. Style and stylistic effects have not been a major concern of modern linguistics. Despite his profound neo-grammarian education, one of the most important linguists working on stylistics, Leo Spitzer, is usually not considered a linguist but a researcher in literature (Maas 2010: 762-786). However, stylistic effects have a functional basis, at least at the moment of creation and productivity. This converts stylistics into an interesting test for underlying functional principles. The pragmatic contrast of politeness and epistemic mitigation in the case of long sentence adverbs (e.g. Fr. sûrement) with directness in the case of short sentence adverbs (e. g. Fr. sûr) may be considered such a stylistic effect that is generally related to contextual features. Thus, the telephone conversation under (9) and the anecdotes on language in (16) activate the relevant communicative style in natural communication (9) and literature (16). If it is correct that stylistic effects have a functional basis, then we have to ask the question whether there is such a functional basis for the stylistic effect of politeness and epistemic mitigation.

The functional basis seems to be "functional transposition". As a matter of fact, mitigation and politeness are not characteristic of the historical and genetic core function of verb modification. In the above mentioned cases of Fr. naturellement and curieusement, it is not frequent but still possible to reactivate the basic concept if these adverbs are used as modifiers of the 
verb: parler naturellement 'to speak naturally' and regarder curieusement 'to look with curiosity'. These cases do not convey mitigation. Hence, the pragmatic and stylistic effects are features that go hand in hand with the transposition of such adverbs to functions other than verb modification. This explains why certain features (e.g. subjectivization) also hold for transpositions other than sentential functions. Modifiers of adjectives are stylistically neuter when they maintain their qualitative concept (e. g. qualitatively good), but they become stylistically and pragmatically marked when they are used as emphatic subjective intensifiers (e. g. terribly good). The same happens with short adverbs (see, e. g. awful good, which was frequently used until Early Modern English; Hummel 2014a). The general preference for the long forms in the history of language restricted the transposition to adjective modification mostly to the long forms inasmuch as productivity and conceptual transparence is concerned, except for substandard (e.g. terrible malo 'lit. terrible bad' in Chilean slang, Fr. sérieux malade [Álvarez-Prendes, in print]).

The conceptual process entailed by such transpositions is generally described in terms of bleaching or desemanticization. I prefer to replace this negative perspective of "lost features" - which reminds of the simplistic assumption of "corrosion" in traditional diachronic studies - by an analysis which foregrounds the active mental process of conceptual abstraction as a correlate of functional reloading. Totally good and terribly good integrate conceptually incompatible lexical items, but the thing works because the modifiers are metaphorically used as modifiers. In this case, the pragmatic effect is not mitigation but intensification. However, as far as the modifiers awful and terribly are concerned, they undergo abstraction, to the point that the transparency of the underlying concept tends to be lost or not activated in common communication (e. g. terribly old; cf. also the German equivalent furchtbar alt). Hence, transposition indeed provides more abstract and in a certain sense mitigated concepts.

Transposition is an overall feature of long adverbs used for discourse functions, even if a small number of them may have been directly created for this purpose (e.g. calques from Latin or other languages; see Fact 10). Sentential and discourse functions are formally marked by syntactic extraposition (e. g. sentence initial position), pauses (parenthetical usage) or intonation. Once established in usage, these marks may be reduced, as, e. g. in the case of Italian diciamo 'let's say' or certo 'sure', which is often fully integrated in the utterance and prosodically unmarked (Schneider 2007: 205).

As far as epistemic adverbs are concerned, the traditional linguistic test for such sentence adverbs provides evidence for the semantics of transposition:

17. It. ramente viene

'He surely comes'

È sicuro che viene

'It is sure that he comes'

18. It. Ovviamente viene

'He obviously comes'

È ovvio che venga

'It is obvious that he comes' 
This test shows that such sentence adverbs attribute the qualities 'sure' or 'obvious' to the proposition from the subjective point of view of the speaker. In other words, they are means of subjectively presenting the propositional content. The test further shows that this attributive relation is basically adjectival in nature: the propositional content 'is sure', 'is obvious', etc.

It comes as no surprise, then, that spontaneous registers tend to use the short form, be it in Romance, English, Dutch, or German. This is the simplest direct way to express what is meant. Consequently, the long adverbs constitute a less direct, transposed way of presenting the propositional content. Conceptual adaptation is not necessary since the paraphrases 'it is sure/obvious that' work perfectly. It seems that the basic effect stems from the functional transposition from the source domain semantics of -mente adverbs, that is, 'event-manner', to the semantics of the target domain, that is, 'state-manner'. This, in turn, explains why the alternatives in (17) and (18) are not fully equivalent, the long variant conveying "the speaker's epistemic evaluation", his personal 'way of seeing things', in contrast to the more direct evaluation expressed by the short form (Ramat/Ricca 1998: 194). Obviously, the similarities we observe between It. sicuramente, sicuro, è sicuro che have to be situated at the semantic level of sentential modification, disregarding crucial syntactic and prosodic differences, which are also related to code preference, e. g. orality in the case of sicuro. In other words, the semantic nucleus of all three forms is basically the same. In this sense, it is correct to say that the modification operated by the adverb sicuramente comes close to the adjectival type 'in my view, it is sure that'.

The fact that the attributive relation established by epistemic adverbs is rather adjectival in nature is further corroborated by stylistically odd but perfectly usual complementation:

19. It. Sicuramente che viene

It. Ovviamente che viene

In his landmark study, Greenbaum (1970: 7-8) analyzes such utterances as instances of "correspondence", that is, surface effects of still underlying adjectival modification: $\grave{E}$ sicuro/ovvio che viene 'It is sure/obvious that he comes' (see Borillo 1976; Pecoraro/Pisacane 1984: 23; Martín Zorraquino 1994; Ramat/Ricca 1998: 213-214; Bosque 2015: 77; Cruschina/Remberger 2017).

From the pragmatic perspective, indirectness created by transposition is a device that is frequently used for mitigation and politeness (Brown/Levinson 1987: 132-144). Possibly, the event-manner origin of long adverbs conveys the feature 'way of seeing things' rather than 'It is like this', the latter being the feature activated by the short form. Event-manner seems to be particularly relevant for domain adverbs ("viewpoint" according to Quirk et al. 1995: 568569) such as historically 'from the point of view of history' since they express ways of seeing things, while the feature "politeness" is less relevant. In the case of long epistemic adverbs, the relevant feature is communicative indirectness, which may be associated with politeness, and, in some languages, with inferentially reduced truth value.

To conclude, the pragmatic and stylistic effects of mitigation and politeness can indeed be related to functional properties of sentence adverbs caused by a series of transpositions from baseline verb modification to peripheral functions. Transposition is not a specific feature of long epistemic adverbs. Consequently, the relevant pragmatic effects are not restricted to this 
group. In the case of domain adverbs, politeness and mitigation are not directly relevant, possibly because the functional feature required is simply event-manner 'way of seeing things'. This does not exclude their belonging to eloquent and polite style. Integrated into texts such as (16) or oral registers such as (9), they receive and reinforce the stylistic effect at the text level. In fact, communication dealing with everyday topics is not likely to use domain adverbs abundantly. In other words, the series of long domain adverbs in Romance or English belong to elaborated style. Historically, they may be seen as correlates of language elaboration ("Sprachausbau", Kloss 1967, 1978), the same as the whole group of long sentence adverbs.

\section{Fact 10: Modern subjectivity, prose, and the genre of the novel}

Subjectivity in language and discourse has been one of the most discussed topics in linguistics over the last decades. Several disciplines converge at this point: discourse analysis (discourse markers, discourse construction), conversational analysis, studies on spoken language (supposed to be particularly subjective). Long sentence adverbs have played a prominent role in this discussion (see e. g. Ricca 2008; Kerbrat-Orecchioni 1980: 118-120; Ernst 2009; Company Company 2014b; among many others). In fact, long adverbs transposed from the verb phrase tend to convey subjectivity (epistemic, emotional, expectative evaluation) or points of view (domain adverbs), even if the modification concerns a single constituent (e. g. the adjective in terribly good). The usage of long sentence adverbs in order to linguistically express subjectivity can thus be considered a well-established synchronic fact.

Most of the linguistic studies on subjectivity stick to synchrony. Now, the recent interest in the diachronic development of long adverbs provides evidence for the existence of historical and cultural conditions that favored the ascendance of long adverbs (see Facts 7 and 8). Fact 9 has pointed out standardization and linguistic ideals as favorable conditions for the expansion of long sentence adverbs. However, this allows, at best, the assumption that (i) high frequency and fashion of long adverbs mainly used for verb modification stimulated their transposition to other functions in the utterance and that (ii) standardization canonized the results. It is hard to believe, however, that transposition has only a causal explanation, that is, the pressure created by frequency and fashion. Many linguists only look for causal explanations supposed to "trigger", "select", "cause" a given linguistic result. However, language is basically driven by finality, that is, the speakers' desire to convey messages. Hence, we have to ask what a linguistic device is used for. Obviously, a widespread phenomenon requires a rather general explanation.

In an interesting paper, González de Requena Farré (2015) relates the expansion of long sentence adverbs to the philosophical debate on upcoming "modern subjectivity" between 1500 and 1950. According to this approach, self-awareness and self-certainty of individual subjects mark the turning point to modernity. The modern subject becomes the epistemic center of the world, which includes a consciousness of relativity, replacing God-given truth. A given opinion is only one of the many opinions (subjective evaluations) and perspectives ("points of view") a single person may develop for the same phenomenon, and, what is more, it is only one opinion among the many opinions other speakers may suggest and defend. Subjectivity and the subordination of truth to subjectivity are direct consequences of this consciousness. Interestingly, González de Requena Farré uses long sentence adverbs for a quanti- 
tative diachronic approach to the historical phenomenon of modern subjectivity. His analysis of long sentence adverbs with evaluative, expectative (e.g. lógicamente), or epistemic value in the diachronic Spanish CORDE corpus (190 million words) provides a curve similar to the one in Figure 2. It would obviously be naïve to think that the frequency of long sentence adverbs directly corroborates modern subjectivity. At least in the context of this paper, the reasoning would be circular. But the rise of long adverbs certainly correlates with independent insights from other disciplines on modern subjectivity (see Folger/Nina 2016 in the domain of literature). Long sentence adverbs can possibly be considered as emblematic linguistic devices in the cultural context of modern subjectivity.

It is noteworthy that the discussion tends to overgeneralization. One must doubt that rural registers of language were/are profoundly affected by "modern subjectivity". If some long adverbs are used in those registers, this possibly happens for the simple reason that they are considered more correct (because the teacher says so) or simply "better" (see "linguistic prestige" in Fact 2). Importantly, diachronic corpora only provide evidence based on written texts. Consequently, the modern-subjectivity hypothesis has to be related and restricted to traditions of (intellectual) writing.

The stylistic and normative rupture that happened in the $17^{\text {th }}$ century (see Fact 8 ) went hand in hand with the change in the center of interest in literature from poetry to prose. This process culminated with the hegemony of the novel genre in the second half of the $19^{\text {th }}$ century. In this context, long adverbs were used for two major concerns, narrativity and subjectivity: Closely related to the ideals of eloquence and fluidity, long adverbs replaced prior parenthetical and declamatory style, the latter being opposed to narration, and the expansion of long sentence adverbs clearly supported the purpose of subjectivity. The peak of expansion is located in the second half of the $19^{\text {th }}$ century and the beginning of the $20^{\text {th }}$ century, that is, the glory period of the novel. At the same time, scientific and other intellectual texts underwent differentiation and reflected cultural innovation. According to Gómez-Jordana (2011: 87), long sentence adverbs specifically add subjective functions to their polyfunctionality during the $19^{\text {th }}$ century, while the $20^{\text {th }}$ century subsequently sees their further pragmaticization, e. g. their independent use as answers (e.g. Fr. Décidément!).

Nineteenth century novels are conceived as heteroglossic universes where many-sided narrators present (or non-overtly present) the figures as persons feeling, thinking, and acting in a subjective way (see e. g. the landmark study by Stanzel 1964; as well as Ullmann 1957). Secondary predication, that is, the use of inflected adjectival variants of short adverbs, expands at the same time. Secondary predicates are primarily used as a literary technique in order to economically express the figures' mental and physical disposition during the events in which they are involved. Now, novels are highly represented in most diachronic corpora. Hence, the analysis of long sentence adverbs in CORDE by González de Requena Farré mainly mirrors what linguistically happened in novels. This means that the results cannot simply be extrapolated to society or language in general, especially as far as informal orality is concerned. In addition, it is also highly improbable that texts written in the domains of law and administration followed the path of subjectivization.

Since Schiffrin (1987), discourse analysis accumulates evidence for the fact that short and shortened forms, the so-called discourse markers, are preferred in informal spoken language. 
It is further generally acknowledged that (short) oral discourse markers play a relevant role in subjective presentation and evaluation. It is hard to believe that this type of subjectivity did not exist in informal spoken language before the modern linguistic epoch. Subjectivity clearly is not a property of written texts. Consequently, the expansion of long adverbs has to be more specifically related to standardization, written language, (literary) style, text types, literary genre, norm and correctness, and intellectual topics such as modern subjectivity. They pertain to a specific technique of presenting one's own or the others' saying, thinking, and feeling. A long series of epistemic adverbs expressing subtle conceptual differences have been developed. This technique seems to be related to the intellectual stream of "modern subjectivity". It correlates with the history of ideas, not with baseline subjectivity. Interestingly, Company Company (2017) observes that the usage of long adverbs goes hand in hand with syntactic complexity, needing extensive contextual information to be clearly disambiguated. By contrast, the corresponding short forms only require a minimum of context. In other words, the former belong to elaborated techniques of presenting propositional contents, whereas the latter realize a rather direct presentation.

To conclude, long adverbs diachronically correlate with "modern subjectivity" as it has been developed especially in the novel, and probably also in essays (cf. "viewpoint"/domain adverbs). It consists of explicating the various subjective interpretations of a given proposition. It therefore correlates with what has been described as a particularly "personal" view of things that complementarily admits divergent points of view. Long adverbs are emblematic for this historical and cultural movement tied to written language. The fact that they progressively penetrated the spoken language of the educated and to a lower degree general informal communication may therefore be seen as a phenomenon that mirrors the impact of "modern subjectivity" in everyday life, where static truth values warranted by religion have been replaced by individual truth, that is, opinion.

\section{Discussion}

I have pretentiously presented the arguments in Section 2 as "facts". I have indeed provided evidence for many aspects. It is certainly clear that this rough overview requires further discussion and empirical investigation. I claim, however, that the ten facts will be crucial for any description and explanation of long sentence adverb use that brings together functional, cultural, and historical aspects. This paper has tried to elaborate the analyses to a maximum of synthesis. This certainly entails the risk of overgeneralization and extrapolation. Consequently, the paper essentially suggests elements for explanation that require further empirical corroboration.

\subsection{Long epistemic adverbs}

Many of the adverbs discussed and cited in this paper do not belong to the group of epistemic adverbs, even if this term is taken in a broad sense (including evidential adverbs; cf. the critical remarks in Haßler 2014). This wide-ranging viewpoint is, however, justified, inasmuch as the historical dynamics of creating such adverbs, their relation to elegant narrative style, mitigation effects, and transposition from verb modifying functions, etc., are not an exclusive property of epistemic adverbs. These adverbs are historically and functionally integrated into 
a more far-reaching dynamic process. It was therefore important to refer to a broad setting of the relevant facts. Within the whole group of sentence adverbs, epistemic and evidential adverbs are particularly sensitive to mitigation.

\section{2 "Noise in the channel"}

It has been argued that long adverbs transposed from the verb phrase tend to convey subjectivity and points of view. There are exceptions however, e. g. time adverbs such as Sp. inmediatamente 'immediately' or units used for discourse organization, e. g. Sp. primeramente 'firstly'. These units do not convey subjectivity, mitigation, or points of view. Nevertheless, sentences that start with such adverbs are characteristic of narrative and argumentative style, and primeramente belongs to a very refined and polite register. Hence, there are at least some features shared with long epistemic adverbs. A similar case is Fr. longuement expressing time; interestingly, Anscombre (1990) analyzes its conceptual opposition to longtemps 'a long time' in terms of "durée subjective et durée objective". In sum, these examples show that subjectivization and mitigation are not common features of all transposed long adverbs. They corroborate, however, the heuristic value of the features identified in the previous sections for long adverbs. Subjectivity may not be shared, while narrativity and argumentativity indeed are, albeit possibly only for certain positions in syntax.

The fact that not all transposed long adverbs share the same features explains why empirical studies which are strictly based on syntax do not provide exactly the same curve as the one in Figure 2. There is noise in the channel. This is the case for Company Company's (2014a) study on Spanish diachrony. The corpus explored by this author is more balanced with regard to types of texts and texts close to spoken language than CORDE. This is probably one reason why the diachronic growth of discourse functions is less exponential in Company's data (2014a: 541). The other reason is that adverbs such as the ones in the previous paragraph are included by Company Company because their scope involves the whole sentence, or parts of it.

Interestingly, in another study on the same corpus, Company Company (2014b) restricts her analysis to long adverbs used as discourse markers, a notion which definitively excludes adverbs of time or space. She then describes the diachronic process of developing discourse functions in terms of subjectivization. At the same time, the diachronic development ends up matching with the curve in Figure 2 (2014b: 26). This means that the idealized curve in Figure 2 more specifically mirrors the development of long adverbs used for the subjective presentation of propositions. This includes long epistemic adverbs.

Another source of "noise in the channel" is Latin. On the one hand, many adverbs do not directly originate in Romance itself, that is, they are not inherited via oral tradition. On the other hand, many of the non-inherited adverbs are not borrowed from Classical Latin either (or other languages). What I mean is that many adverbs, and in particular sentence adverbs, are calques or loan translations from Latin as it was written and spoken before the Renaissance tried to rule out all idiosyncratic discrepancies from Classical Latin in the so-called dog or kitchen Latin. This means that traditional diachronic analyses in terms of inherited and borrowed items run short of evidence. We must instead assume a rather intimate and intuitive relation of incipient Romance and current practice of spoken and written Latin in the con- 
science of the educated. This seems to be particularly relevant for discourse organization. Ricca (2008, 2010: 149-152) provides broad evidence for this, e. g. It. probabilmente and Lat. probabiliter, as well as Lat. certe, breviter, etc., even if no systematic analysis of the transmission process is available for the moment. In fact, the process of calquing or loaning is not directly evident, except in translations, which could be explored for this purpose. However, many authors "feel" the Latin origin of sentence adverbs. According to Iglesias Recuero (2007; also see Garcés Gómez 2009), Sp. finalmente was directly created as a discourse marker as early as the $13^{\text {th }}$ century, together with al fin/a la fin, as substitutes for Lat. in/ad fine ( $m$ ) and in fine (see also Pons Rodríguez 2010). González Manzano (2010) links Lat. vero with the use of Sp. veramente/verdaderamente.

Consequently, sentence adverbs formed according to Medieval Latin models obviously do not share the smooth path of transposition from the verb phrase to peripheral functions. They do not even follow the curve in Figure 2. This curve primarily concerns what happened after the $17^{\text {th }}$ century rupture with tradition. This leads to a differentiated analysis of polyfunctional sentence adverbs, as we shall now see.

\subsection{Polyfunctionality}

Some of the sentence adverbs have developed larger series of functions, e. g. sentential modification along with affirmative answer (e.g. Fr. absolument 'absolutely'). Interestingly, short adverbs generally belong to the older (Indo-European) oral tradition of using adjectives for adverbial functions. The long forms, therefore, generally follow the short forms in diachrony if the adjective belongs to the old lexical fund of the language, while the bulk of borrowed adjectives in the modern epochs of language rather systematically adopt a long form for adverbial functions. This has been documented for Modern English (Baugh/Cable 1986: 178). Most modern sentence adverbs are loan words, generally from Classical Latin (eventually via other languages). All the items listed under (11) are loan words which genuinely belong to the language of the educated. In the modern epoch, the language of the educated preferred to directly create deadjectival adverbs ending in -mente (or Engl. -ly), thus avoiding the short forms.

As a consequence of the fact that many sentence adverbs have been directly created as long adverbs, sentence adverbs are a domain where the major diachronic tendency of short adverbs preceding long adverbs (slow > slowly) inverts as transposed adverbs penetrate informal registers of language. A paradigmatic case discussed by Hummel (2013b) is Engl. real good, which can be traced back to previous really as a calque from spoken and written Medieval Latin realiter. Verb modifiers behave similarly. When the adjective Fr. rapide was borrowed in the $17^{\text {th }}$ century, it was soon followed by the adverb rapidement, while the short adverb rapide follows rather late as rapide penetrated informal spoken language, its frequency still being low nowadays (Hummel/Kröll 2015). Similarly, short sentence adverbs such as those cited under (13) were built as short variants of older long sentence adverbs. According to Ricca (2008), It. ovviamente was directly created as a sentence adverb. The analogue function of ovvio probably followed the path opened by the long form. In other words, primary grammaticalization (e. g. Lat. alta mente $>$ Sp. altamente) generally followed the short forms (Lat. alte or altum with adverbial function), while in the modern epoch of Romance the subsequent 
secondary grammaticalization of discourse functions (Sp. curiosamente 'with care' > 'strangely') often started with the long form, occasionally producing also a short form with the same or a similar discourse function.

In her study on Fr. sérieux/sérieusement, Álvarez Prendes (in print) observes and attests the same three functions for the long and the short adverb: sentence adverb (mostly sentence initial), verb modification, and intensification (sérieux malade/sérieusement malade 'serious(ly) sick'). This provides evidence for the close relationship between the long and the short variant. Even if no diachronic evidence is available, the widespread usage of sérieusement and the marginal usage of sérieux suggest the genetic priority of the long form. It would obviously be of great interest to study the diachrony of these forms and functions, but the restricted documentation of the informal spoken language in written documents will probably make it impossible. However, Gerhalter (2013) has brought to light this type of diachrony for highly frequent Sp.justo/justamente.

Conversely, traditional polyfunctional discourse markers such as Fr. certes, It. certo, and Sp. cierto, which had widespread usage in the old and middle epochs, were the starting point for certainement, certamente, ciertamente, if the starting point was not Lat. certo for all of them. According to Ricca (2008: 7), It. certamente is the only long adverb in his sample whose epistemic sentential function is documented since 1300. Since its first attestations, It. certo was only used as a sentence adverb. Dardano (2012) counts certo, not certamente, among the discourse markers used in Old Italian poetry. Since the diachronic core function of certamente was verb modification, it seems plausible that its sentential functions followed those of certo, at least in part (see Espinoza Elorza 2009: 123). In sum, the nice picture of functional, conceptual, and morphological transposition from the short form to the long one, or conversely, from the verbal phrase to peripheral positions in syntax, requires a differentiated analysis. However, this does not invalidate the major tendency by which subjectivization, mitigation, politeness, and elaboration appear as properties which are particularly prominent amongst the long forms in many of their functions. The important point is that this tendency has to be located in the modern epoch. In this sense, the "noise" confirms the historical and cultural explanation (Facts 8, 9, 10).

\subsection{Politeness}

In the following citations, It. certo is used in very polite contexts:

20. "Sì, certo", rispose Duca sostenendolo per un braccio, "andiamo su a casa sua, un momento, a parlare." (Scerbanenco 2014: 38)

21. "Certo, siamo venuti per questo", disse Duca, "ma prima devo parlarle" (ibid.: 40)

Certo is used here by interlocutors addressing each other with respectful and polite Lei 'you, Sir', a feature I have used to characterize certamente in (8). Comparing (8) to $(20,21)$, the pertinent difference seems to be the narrative style ("fluency") introduced by certamente, as is also the case in the examples under (16), in contrast to parenthetical ("independent") usage. Another difference is that in other contexts certo is easily compatible with the informal allocution pronoun $t u$ 'you' (informal), while it is hard to imagine certamente in an informal conversation of people using tu. This also holds for Sp. ciertamente in (8). Hence, politeness is 
not an exclusive property of long adverbs, but long adverbs are more closely intertwined with (formal, respectful) politeness. Obviously, the use of It. certamente in an informal conversation where the interlocutors address each other with $t u$ cannot be definitively excluded. Yet, certamente still would mark an instantaneous attitude of respect.

\section{Conclusion}

I have started with the observation that long epistemic adverbs convey a particular type of epistemic mitigation going hand in hand with politeness. It has then been shown that "epistemic mitigation" is an intuitive term that hides a complex bundle of factors converging at different levels, which may be perceived as variants of mitigation (subjectivization, lower commitment to truth, politeness, indirectness, better language). This phenomenon has then been culturally located in the modern epoch of languages sharing the same Western tradition. After the rupture with tradition in the $17^{\text {th }}$ century, the French model of eloquence, fluidity, and moderation gave advantage to the usage of long adverbs, supported by the normative linguistic tradition of preferring morphologically marked adverbs in the written standard. While the fashion of using the long form and its narrative usage in prose concerned long adverbs in general, the so-called subjectivization in discourse involved, in particular, evaluative and epistemic adverbs, as well as domain adverbs, also called "adverbs of point of view". More concretely, these adverbs were used to express concepts that nuance the subjective presentation and evaluation of propositional contents. From the point of view of the history of ideas, this can be interpreted as a mirror of "modern subjectivity" where truth is in the hands of the individual person. The individual person has in turn to respect the opinion (or claim for truth) of others. The idealized curve in Figure 2 illustrates the transposition of long adverbs (generally) from verb modification to peripheral, rather subjective functions. This movement clearly accompanies the propagation of the novel as the paramount genre in literature and the rise of scientific discourse during the second half of the $19^{\text {th }}$ century. The $20^{\text {th }}$ century canonizes the subjectivization functions of long adverbs, adding more pragmatics facets, especially as a consequence of their increasing penetration into informal oral registers. Unlike Italian, which sticks to baseline subjectivization, epistemic adverbs in French, Portuguese, and Spanish have undergone a subsequent process that inferentially interprets epistemic subjectivity as a lower commitment to truth, even in subjective terms. Finally, even if this wide panorama resembles an essay at times, I claim that in any description of long sentence adverbs that might later be developed, the ten facts will be relevant.

\section{Corpora}

$\mathrm{CDH}$, http://corpus.rae.es/creanet.html.

CORDE, http://corpus.rae.es/cordenet.html.

Linguee, https://www.linguee.de.

\section{References}

Albanese, Antonio (2011): Qualunquemente, movie directed by Giulio Manfredonia, https://en.wikipedia.org/wiki/Qualunquemente, [29.6.2016].

Álvarez-Prendes, Emma (in print): «L'adverbe sérieusement et l'adjectif-adverbe sérieux: Étude contrastive de leurs emplois et leurs propriétés ». In: Loureda, Óscar/Rudka, 
Martha/Sellán, Guillermo (eds.): Marcadores del discurso y lingüistica contrastiva en las lenguas románicas.

Arjona Iglesias, Marina (1991): «Los adverbios terminados en -mente». In: Arjona Iglesias, Marina (ed.) : Estudios sintácticos sobre el habla popular Mexicana. México/D. F., UNAM: $25-63$.

Anscombre, Jean-Claude (1990): «L'opposition longtemps / longuement: Durée objective et durée subjective ». Langue française 88: 90-116.

Bally, Charles ( $\left.{ }^{4} 1965\right)$ : Linguistique générale et linguistique française. Bern: Francke.

Barrios Sabador, María José (2015): "Variabilidad del discurso oral: el caso de seguramente. Un análisis comparativo con quizá(s) y a lo mejor». Verba hispanica 23: 61-84.

Baugh, Albert C./Cable, Thomas ( $\left.{ }^{3} 1986\right)$ : A History of the English Language. London/New York: Routledge \& Kegan.

Biber, Douglas (1988): Variation Accross Speech and Writing. Cambridge etc.: Cambridge University Press.

Biber, Douglas et al. (1999): Longman Grammar of Spoken and Written English. Harlow: Longman.

Bilger, Mireille (2004): "Quelques données sur les adverbes en -ment dans le corpus de référence de [sic] français parlé ». In: Recherches sur le français parlé 18 (Autour du corpus de référence du français parlé). Aix-en-Provence, Publications de l'Université de Provence: $63-81$.

Bischoff, Heinrich (1970): Setzung und Transposition des -mente-Adverbs als Ausdruck der Art und Weise im Französischen und Italienischen mit besonderer Berücksichtigung der Transposition der Adjektive. Zürich: Juris.

Borillo, Andrée (1976): «Les adverbes et la modalisation de l'assertion ». Langue française 30: 74-89.

Bosque, Ignacio (2015): «Usos modales de los adverbios de facilidad y dificultad». In: Galán Rodríguez, Carmen et al. (eds.): El discurso de la gramática. Estudios ofrecidos a José Manuel González Calvo. Cáceres, Universidad de Extremadura: 75-87.

Brenes Peña, Ester (2013): «Adverbios y expresiones enunciativas de sinceridad. Valores argumentativos y efectos (des)corteses». Oralia 16: 33-58.

Briz, Antonio (2016): «Evidencialidad, significados pragmáticos y partículas discursivas en español. Sobre la intensificación tácitamente evidencial». In: González Ruiz, Ramón/Izquierdo Alegría, Dámaso/Loureda Lamas, Óscar (eds.): La evidencialidad en español: Teoría y descripción. Madrid/Frankfurt a. M., Iberoamericana/Vervuert: 103127.

Brown, Penelope/Levinson, Stephen C. (1987): Politeness. Cambridge: Cambride University Press.

Chafe, Wallace L. (1982): Integration and involvement in speaking, writing, and oral literature. In: Tannen, Deborah (ed.): Spoken and Written Language: Exploring Orality and Literacy. Norwood, Ablex: 35-53.

Chircu, Adrian (2008): L'adverbe dans les langues romanes. Études étymologique, lexicale et morphologique: Français, roumain, italien, espagnol, portugais, catalan, provençal. Cluj Napoca: Casa Cărţii de Ştiinţă. 
Company Company, Concepción (2012): «Condicionamientos textuales en la evolución de los adverbios en -mente». Revista de Filología Española 92/1: 9-42.

Company Company, Concepción (2014a): «Adverbios en -mente». In: Company Company, Concepción (ed.): Sintaxis histórica de la lengua española. Tercera parte: Adverbios, preposiciones y conjunciones. Relaciones interoracionales. México/D. F., Universidad Nacional Autónoma de México-Fondo de Cultura Económica: 457-612.

Company Company, Concepción (2014b): «Principios teóricos vs. datos de corpus: ¿Dialogo o enfrentamiento? Los adverbios en -mente como marcadores de discurso». In: García Negroni, María Marta (ed.): Marcadores del discurso: perspectivas y contrastes. Buenos Aires, Santiago Arcos: 13-33.

Company Company, Concepción (2017): «Adverbial adjectives and -mente adverbs face to face. Diachronic evidence from Spanish ». In: Hummel, Martin/Valera, Salvador (eds.): Adjective Adverb Interfaces in Romance. Amsterdam/Philadelphia: Benjamins.

Cresti, Emanuela/Moneglia, Massimo (eds.) (2005): C-ORAL-ROM: Integrated Reference Corpora for Spoken Romance Languages. Amsterdam/Philadelphia: Benjamins.

Cruschina, Silvio/Remberger, Eva-Maria (2017) : « Before the complementizer. Adverb types and root clause modification ». In : Hummel, Martin/Valera, Salvador (eds.) : Adjective adverb interfaces in Romance, Amsterdam/Philadelphia (John Benjamins) : 81-109.

Dardano, Maurizio (2012): «Segnali discorsivi della prima poesia italiana». In: Wehr, Barbara/Nicolosi, Frédéric (eds.): Pragmatique historique et syntaxe. Frankfurt a. M. etc., Lang: 47-68.

De Cesare, Anna-Maria et al. (forthcoming): «Domain adverbs in the news. A corpus-based contrastive perspective on English, German, French, Italian and Spanish ». Languages in Contrast.

Delbecque, Nicole (2009): «Acerca de la relación entre cierto y seguro». In: Veyrat Rigat, Montserrat/Serra Alegre, Enrique (eds.): La lingüística como reto epistemológico y como acción social. Estudios dedicados al Profesor Ángel López García con ocasión de su sexagésimo aniversario. Vol 1. Madrid, Arco Libros: 629-644.

Diepeveen, Ariane (2012): Modifying Words. Dutch Adverbial Morphology in Contrast. Berlin: FU Berlin.

Downing, Angela (2006): « The English pragmatic marker surely and its functional counterparts in Spanish ». In: Aijmer, Karin/Simon-Vandenbergen, Anne-Marie (eds.): Pragmatic Markers in Contrast. Amsterdam etc., Elsevier: 39-58.

Eberenz, Rolf (2009): «La periodización de la historia morfosintáctica del español: Propuestas y aportaciones recientes». Cahiers d'études hispaniques médiévales 32: 181-201.

Ernst, Thomas (2009): "Speaker-oriented adverbs". Natural Language and Linguistic Theory 27: $497-544$.

Espinosa Elorza, Rosa María (2009): «Factores que afectan a los reajustes de los sistemas de adverbios del español». Cahiers d'études hispaniques médiévales 32: 117-134.

Folger, Robert/Nina, Fernando (eds.) (2016): Subjetividad y naturaleza en las literaturas hispánicas entre 1650-1800, special issue of Ibero 84/1-2.

Fuentes Rodríguez, Catalina (1991): «Adverbios de modalidad ». Verba 18: 275-321.

Fuentes Rodríguez, Catalina (2009): Diccionario de conectores y operadores del español. Madrid: Arco Libros. 
Garcés Gómez, María Pilar (1998): «Formas adjetivas con función adverbial en español». Romanistisches Jahrbuch 49: 283-306.

Garcés Gómez, María Pilar (2006): «La evolución de los marcadores de ordenación discursiva en español». Romanistisches Jahrbuch 57: 327-351.

Garcés Gómez, María Pilar (2009): «El proceso evolutivo de los marcadores de reconsideración». Romanistisches Jahrbuch 60: 215-238.

García Sánchez, Jairo Javier (2007): «Antonimia y sinonimia en el proceso de gramaticalización de los adverbios en -mente». In: Trotter, David (ed.): Actes du XXIV Congrès International de Linguistique et de Philologie Romanes, Aberystwyth 2004. Tübingen, Niemeyer: 419-428.

Gerhalter, Katharina (2013): La polisemia y polifuncionalidad de justo y justamente. Un estudio diacrónico y sincrónico., University of Graz.

Gil, Alberto (1995): Textadverbiale in den romanischen Sprachen. Eine integrale Studie zu Konnektoren und Modalisatoren im Spanischen, Französischen und Italienischen. Frankfurt etc.: Lang.

Glatigny, Michel (1982): «Remarques sur la formation des adverbes en -ment au seizième siècle ». In: Danjou-Flaux, Nelly/Gary-Prieur, Marie-Noëlle (eds.): Lexique 1: Adverbes en -ment, manière, discours. Lille, Presses Universitaires de Lille: 65-90.

Glatigny, Michel (2005): "L'éternel retour des adverbes en -ment. $\mathrm{XVI}^{\mathrm{e}}-\mathrm{XX}^{\mathrm{e}}$ siècle ». In: Goes, Jan (ed.): L'adverbe: Un pervers polymorphe. Arras, Artois Presses Université: 4367.

Gómez-Jordana, Sonia (2010): «L'évolution diachronique des adverbes justement / justamente, apparemment / aparentemente, décidément / decididamente en français et en espagnol ». Vox romanica 69: 206-231.

Gómez-Jordana, Sonia (2011): «Décidément et decididamente: Une évolution à deux vitesses? ». Langages 184: 69-90.

González de Requena Farré, Juan Antonio (2015): «Una historia adverbial de la subjetividad moderna hispanohablante». Logos 25/2: 140-153.

González Manzano, Mónica (2010): «Subjetivización y unidireccionalidad en la evolución histórica del adverbio verdaderamente». Res diachronicae 8: 7-27.

Greenbaum, Sidney (1970): Studies in English Adverbial Usage. London: Longman.

Gülich, Elisabeth (1970): Makrosyntax der Gliederungssignale im gesprochenen Französisch. München: Fink.

Gutiérrez de los Ríos y Córdoba, Francisco, conde de Fernán Núñez (1686/2000): El hombre práctico o discursos varios sobre su conocimiento y enseñanza. Edición crítica de Jesús Pérez Magallón and Russel P. Sebold. Córdoba: Publicaciones Obra Social y Cultural Caja Sur.

Haßler, Gerda (2014): «Adverbes épistémiques dans le français parlé et écrit: Apparemment, évidemment, visiblement, éventuellement, probablement». In: Weidenbusch, Waltraud (ed.): Diskursmarker, Konnektoren, Modalwörter. Tübingen, Narr: 161-174.

Hennemann, Anja (2012): «The epistemic and evidential use of Spanish modal adverbs and verbs of cognitive attitude ». Folia linguistica 46/1: 133-170.

Hernando Cuadrado, Luis Alberto (2006): Gramática del adverbio en español. Madrid: Universidad Rey Juan Carlos. 
Hummel, Martin (2000): «Considerações sobre os tipos ela fala esquisito e ela chega cansada no português coloquial e literário do Brasil e de Portugal ». In: Gärtner, Eberhard/Hundt, Christine/Schönberger, Axel (eds.): Estudos de gramática portuguesa (II). Frankfurt a. M., TFM: 87-123.

Hummel, Martin (2012): Polifuncionalidad, polisemia y estrategia retórica. Los signos discursivos con base atributiva entre oralidad y escritura. Acerca de esp. bueno, claro, total, realmente, etc. Berlin/Boston: de Gruyter.

Hummel, Martin (2013a): «Sincronía y diacronía de los llamados adjetivos adverbializados y de los adverbios en -mente». Anuario de Letras. Lingüística y Filología (Universidad Nacional Autónoma de México) I/2: 215-281.

Hummel, Martin (2013b): «La dimensión intercultural de la expansión diacrónica de los adverbios en -mente». In: Garcés Gómez, María Pilar (ed.): Los adverbios con función discursiva. Procesos de formación y evolución. Madrid/Frankfurt a. M., Iberoamericana/Vervuert: 15-41.

Hummel, Martin (2014a): "The adjective-adverb interface in Romance and English ». In: Sleeman, Petra/Van de Velde, Freek/Perridon, Harry (eds.): Adjectives in Germanic and Romance, Amsterdam/Philadelphia, Benjamins: 35-71.

Hummel, Martin (2014b): «Los adjetivos adverbiales». In: Company Company, Concepción (ed.): Sintaxis histórica de la lengua española. Tercera parte: Adverbios, preposiciones y conjunciones. Relaciones interoracionales. Vol. 1. México/F. D., Universidad Nacional Autónoma de México-Fondo de Cultura Económica: 615-733.

Hummel, Martin (2018a): « Éléments d'une diachronie grammaticographique et normative de l'adverbe français accompagnés de trois méthodes pour mesurer l'effet du discours normatif sur l'usage », Romanische Forschungen 130: 3-35.

Hummel, Martin (2018b): "La structure 'verbe + adjectif'. Parler vrai, dire juste, faire simple et compagnie », Revue Romane 53,2: 261-296.

Hummel, Martin (in print), "The third way: Prepositional adverbials in the diachrony of Romance", Romanische Forschungen.

Hummel, Martin et al. (update 6/2018): "Adjective-adverb interfaces in Romance ", https://adjective-adverb.uni-graz.at.

Hummel, Martin/Kröll, Andrea (2015): «Vite et vitement. Étude diachronique variationnelle d'une exception ». Revue de Linguistique Romane 79: 39-91.

Iglesias Recuero, Silvia (2007): «Marcadores del discurso e historia del español: Al fin, en fin y finalmente». In: Delgado Cobos, Inmaculada/Puigvert Ocal, Alicia (eds.): Ex admiratione et amicitia. Homenaje a Ramón Santiago. Madrid, Ediciones del Orto: 623645.

Kerbrat-Orecchioni, Catherine (1980): L'énonciation de la subjectivité dans le langage. Paris: Colin.

Killie, Kristin (2015): « Secondary grammaticalization and the English adverbial -ly». Language Sciences 47: 199-214.

Kloss, Heinz (1967): « Abstand languages and Ausbau languages ». Anthropological Linguistics 9: 29-41.

Kloss, Heinz (1978): Die Entwicklung neuer germanischer Kultursprachen seit 1800. Düsseldorf: Schwann. 
Kluge, Friedrich ( $\left.{ }^{24} 2002\right):$ Etymologisches Wörterbuch der deutschen Sprache. Berlin/New York: de Gruyter.

Koch, Peter/Oesterreicher, Wulf (2011): Gesprochene Sprache in der Romania. Berlin/New York: de Gruyter.

Kofler, Michaela (2007): Der Gebrauch der Modaladverbien in drei französischsprachigen Romanen von Andreï Makine, Philippe Djian und Alphonse Boudard. Master thesis. University of Graz.

Kortschak, Carmen/Hummel, Martin (2018): "Los adverbios en -mente en los registros formal e informal del español hablado peninsular y mexicano ", Nueva Revista de Filología Hispánica 66/1: 3-42.

Landone, Elena (2009): Los marcadores del discurso y la cortesía verbal en español. Bern etc.: Lang.

Lavale-Ortiz, Ruth (in print): «A cognitive approach to the grammaticalization of the epistemic marker fijo ». In: Fernández Jaén, Jorge/Provencio Garrigós, Herminia (eds.): Historical Linguistics. Current Theories and Applications. Amsterdam/Philadelphia: Benjamins.

Lyons, John (1977): Semantics. 2 vols. Cambridge/London etc.: Cambridge University Press.

Maas, Utz (2010): Verfolgung und Auswanderung deutschsprachiger Sprachforscher 19331945. Tübingen: Stauffenburg.

Maas, Utz (2012): Was ist Deutsch?. München: Fink.

Marino, Giambattista (1620 [=1614]), La lira (original edition digitalized by Bayrische Staatsbibliothek).

Martín Zorraquino, María Antonia (1994): «Sintaxis, semántica y pragmática de algunos adverbios oracionales asertivos en español actual». In: Demonte, Violeta (ed.): Gramática del español. México/D.F., El Colegio de México: 557-590.

Martín Zorraquino, María Antonia (2015): «De nuevo sobre los signos adverbiales de modalidad epistémica que refuerzan la aserción en español actual: Propiedades sintácticas y semánticas y comportamiento discursivo». In: Engwall, Gunnel/Fant, Lars (eds.): Festival romanistica. Stockholm, University Press: 37-63.

Mayol, Laia/Castroviejo, Elena (2013): « (Non)integrated evaluative adverbs in questions: A cross-Romance study ». Language 89/2: 195-230.

Moreno de Alba, José G. (1996): Nuevas minucias del lenguaje. México/D. F.: Fondo de Cultura Económica.

Orlando, Virgina (ed.) (2006): Mecanismos conversacionales en el español del Uruguay. Análisis de interacciones telefónicas de servicios. Montevideo: Universidad de la República/Facultad de Humanidades y Ciencias de la Educación.

Pecoraro, Walter/Pisacane, Chiara (1984): L'avverbio. Bologna: Zanichelli.

Pons Rodríguez, Lola (2010): «La elaboración lexica desde modelos latinos: Tres estudios de caso en el castellano medieval (inclusive, exclusive, respective)». In: Castillo Lluch, Mónica/López Izquierdo, Marta (eds.): Modelos latinos en la Castilla medieval. Madrid/Frankfurt a. M., Iberoamericana/Vervuert: 81-111.

Pounder, Amanda (2001): "Adverb-marking in German and English ». Diachronica 18/2: 301-358. 
Quirk, Randolph et al. ('1995): A Comprehensive Grammar of the English Language. London/New York: Longman.

Ramat, Paolo/Ricca, Davide (1998): « Sentence adverbs in the languages of Europe ». In: van der Auwera, Johan (ed.): Adverbial Constructions in the Languages of Europe. Berlin/New York, Mouton de Gruyter: 187-275.

Ricca, Davide (2008): «Soggettivizzazione e diacronia degli avverbi in -mente: Gli avverbi epistemici ed evidenziali». In: Lazzeroni, Romano et al. (eds.): Diachronica et synchronica. Studi in onore di Anna Giacalone Ramat. Pisa, ETS: 429-452.

Ricca, Davide (2010): "Adverbs ». In: Baldi, Philip/Cuzzolin, Pierluigi (eds.): New Perspectives on Historical Latin Syntax. Vol. 2: Constituent Syntax, Adverbial Phrases, Adverbs, Mood, Tense. Berlin/New York, de Gruyter: 109-191.

Rivas, Javier/Sánchez-Ayala, Ivo (2012): «Procesos de gramaticalización en el desarrollo de las aportaciones reactivas: el caso de efectivamente». In: Montero Cartelle, Emilio (ed.): Actas del VII Congreso Internacional de Historia de la Lengua Española. Vol. 2. Santiago de Compostela, Meubook: 2363-2374.

Rodríguez Somolinos, Amalia (2012): «L'évolution de apparemment en français: La formation d'un marqueur d'attitude énonciative ». In: Combettes, Bernard et al. (eds.): Le changement en français. Bern etc., Lang: 345-361.

Sánchez Jiménez, Santiago (2008): «La créación de un marcador del discurso: naturalmente». In: Elvira, Javier et al. (eds.): Lenguas, reinos y dialectos en la Edad Media Ibérica. Madrid/Frankfurt a. M., Iberoamericana/Vervuert: 435-468.

Santos, Francisco (1991 [=1671]), El rey gallo y discursos de la hormiga, edición crítica de Víctor Arizpe, London: Tamesis.

Scerbanenco, Giorgio (2014): I milanesi ammazzano al sabato. Milano: Garzanti.

Schiffrin, Deborah (1987): Discourse Markers. Cambridge: Cambridge University Press.

Schneider, Stefan (2007): Reduced Parenthetical Clauses as Mitigators. A Corpus Study of Spoken French, Italian and Spanish. Amsterdam/Philadelphia: Benjamins.

Seco, Manuel/Andrés, Olimpia/Ramos, Gabino (1999): Diccionario del español actual. 2 Vols. Madrid: Aguilar.

Simon-Vandenbergen, Anne-Marie/Aijmer, Karin (2007): The Semantic Field of Modal Certainty. Berlin/New York: Mouton de Gruyter.

Simon-Vandenbergen, Anne-Marie/Willems, Dominique (2011): «Crosslinguistic data as evidence in the grammaticalization debate: The case of discourse markers ». Linguistics 49/2: 333-364.

Solís García, Inmaculada (2012): «Instrucciones procedimentales de los marcadores evidenciales en efecto y efectivamente». Pragmalingüística 20: 239-254.

Spitzer, Leo (1931): « Die Klassische Dämpfung in Racines Stil ». In: Spitzer, Leo (ed.): Romanische Stil- und Literaturstudien. Vol. 1. Marburg, Elwert'sche Verlagsbuchhandlung: 135-268.

Stanzel, Franz K. (1964): Typische Formen des Romans. Göttingen: Vandenhoeck \& Ruprecht.

Swan, Toril (1991): "Adverbial shift: Evidence from Norwegian and English ». In: Kastovsky, Dieter (ed.): Historical English Syntax. Berlin/New York, Mouton de Gruyter: 409-438. 
Tagliamonte, Sali/Ito, Rika (2002): " Think really different: Continuity and specialization in the English dual-form adverbs ». Journal of Sociolinguistics 6/2: 236-266.

Thompson, Sandra A./Mulac, Anthony (1991): « A quantitative perspective on the grammaticization of epistemic parentheticals in English ». In: Traugott, Elizabeth C./Heine, Bernd (eds.): Approaches to Grammaticalization. Vol. 2: Focus on Types of Grammatical Markers. Amsterdam/Philadelphia, Benjamins: 313-329.

Ullmann, Stephen (1957): Style in the French Novel. Cambridge: University Press.

Vázquez Rozas, Victoria (2010): «Sobre seguro: Del riesgo presupuesto a la certeza epistémica”. In: Rodríguez-Espiñeira, María-José (ed.): Adjetivos en discurso. Emociones, certezas, posibilidades y evidencias». Santiago de Compostela, Universidade de Santiago de Compostela: 109-146.

Weydt, Harald (1969): Abtönungspartikel. Die deutschen Modalwörter und ihre französischen Entsprechungen. Bad Homburg: Gehlen. 